\title{
ECONOMIC DEVELOPMENT IN THE MODEL CITIES PROGRAM
}

\author{
Charles E. Olken*
}

\section{INTRODUCTION}

The Model Cities program, ${ }^{1}$ begat in the Great Society, altered and redirected under the New Federalism, and victimized by a continuing love-hate relationship with virtually all the politicians, bureaucrats, and community people who touch and are touched by it, continues to exhibit one key strength. It is the most highlyendowed source of non-categorical funds for urban development available in this nation; and Model Cities funds are now being used on a regular basis to support virtually all functions involved in community economic development, including economic planning, feasibility and market studies, venture capital on both equity and loan (including subordinated and low-interest) bases, land purchases and options, staff costs for business packaging and management assistance, management training, industrial promotion, direct loans, revolving loan and loan-guarantee pools, and bonding pools for minority contractors. Although the program may never achieve its widely heralded goals of breaking the poverty cycle in the chosen model neighborhoods and rationalizing governmental funding processes, the fervor with which it is being pursued and the relative flexibility of its resources attract the attention of those concerned with the urban scene in all aspects, including economic development by community development corporations.

It is important to note that the Model Cities program, unlike most other sources of funds relevant to economic development, asks that problem analysis and projectactivity programming be approached on a comprehensive basis. ${ }^{2}$ Cities are expected to develop strategies which are appropriate for the observed local pathology, emphasizing those factors most in need of change if the urban condition is to be improved. Thus, while comprehensive problem analysis is essential, the program initially undertaken to treat a given neighborhood's ills must concentrate on the key local variables. The theory followed here suggests that if strategic barriers are eliminated first, the other barriers to social change can fall more easily and in a more controlled manner.

The early Model Cities experience indicated that the depth of economic deprivation was widely recognized. However, the first plans also revealed that fewer cities than might have been expected were adopting strategies built around economic development, even though this generic area was given a high priority rating in terms

\footnotetext{
* Economic Development Advisor, United States Department of Housing and Urban Development, San Francisco Regional Office.

${ }^{2} 42$ U.S.C. $\$ 3301$ et seq. (Supp. V, x970).

${ }^{3}$ Id. $\S 330 \mathrm{I}$.
} 
of need for programming and was, in fact, receiving some attention in most plans. In most cases, the underlying problem was a lack of knowledge regarding economic development, which led to reluctance on the part of residents, CDA staff, and city councils to program heavily in this area. Our recent experience suggests a gradual increase in emphasis on economic development.

\section{I}

\section{Background and Substance of the Moded Cities Program}

In October 1965, as part of his attempt to supplant the New Frontier with his Great Society, President Johnson appointed a special Task Force on Urban Problems headed by Robert C. Wood, then chairman of the Political Science Department of Massachusetts Institute of Technology.3 The efforts of that group produced the basic concept of a new administration thrust, first heralded in President Johnson's January Ig66 State of the Union Message. ${ }^{4}$ His call for added public and private efforts to eliminate urban blight was supplemented by a special message to the Congress two weeks later entitled City Demonstration Programs. ${ }^{5}$ On the next day, legislation to implement the President's proposals was introduced as H.R. I234I and S. 2842, the Demonstration Cities and Metropolitan Development Act of I966. After lengthy hearings and deliberations, the bill became law on November 3 , r $966 .^{\circ}$

Title I of the act authorized HUD to provide grants and technical assistance to cities to assist them in planning and carrying out local programs. According to HUD, these programs must provide "for a comprehensive attack on social, economic, and physical problems in selected slum and blighted areas through concentration and coordination of Federal, State, and local public and private efforts."

Admission to the program required an application for a grant to plan a comprehensive program. The essential elements of such a plan, upon which specific projects are based, are a probing analysis of conditions and causes, a statement of long-range goals and program approaches, and an indication of the underlying strategy for attacking problems in a comprehensive manner. According to HUD, comprehensive programs should "encompass all of the deep-rooted social and environmental problems of a neighborhood." " HUD's working definition of "comprehensive" derives from the legislative purposes stated in section Ior of the Act, where the call for improvements in housing, income opportunities, education, health, criminal justice, transportation, and living conditions is manifested.9

\footnotetext{
${ }^{3}$ Other Task Force members were Kermit Gordon, Charles Haar, Ben W. Heineman, Edgar Kaiser, William Rafsky, Walter P. Reuther, Abraham Ribicoff, and Whitney Young.

H.R. Doc. No. 32r, 89th Cong., 2d Sess. (I966).

${ }^{5}$ H.R. Doc. No. 368, 89th Cong., 2d Sess. (Ig66).

- Demonstration Cities and Metropolitan Development Act of 1966, Pub. L. No. 89-754, 80 Stat. r255.

7U.S. Dep'T of Housing aNd URBan Development, Improving THE Quality of Untan Life I $(1967)$.

${ }^{8}$ Id. at 3.

${ }^{8} 42$ U.S.C. $\$ 3301$ (Supp. V, 1970).
} 


\section{A. Citizen Participation}

The community is guaranteed an active role in model cities by virtue of the enabling legislation, which requires "widespread citizen participation in the program ...."10 Although the Republican Administration has chosen to de-emphasize this aspect of Model Cities, Secretary Hyde and his chief aides continue to demand that cities clearly define and set forth the responsibilities of citizens in such a way as to insure their continuous and meaningful involvement. At the same time, it has become abundantly clear that this Administration makes a sharp distinction between citizen participation and citizen control and will not tolerate the latter in the planning process, whether it arises from either city indifference or effective community political action.

The early evaluation of this stance indicates a mixed bag of new opportunities and dangers for community-based economic development. HUD's position was not intended to discourage, and has not prevented, citizen control of new operating agencies, such as development corporations. But city councils, which have the final say in choice of program activities, have succumbed to Chamber-of-Commerce-type pressures against economic development by substituting less threatening (frequently manpower training) projects. The unanswered question is whether this kind of tampering with citizen initiative in economic development will increase or decrease as the Model Cities program matures. Hopefully, there is nothing so powerful as an idea when its time has come.

\section{B. The Early Model Cities Response to Economic Issues}

The Model Cities program was born at a time when the primary economic considerations in social planning were income levels and job training. Interest in community economic development had not emerged as a focal point in urban rhetoric, nor had the usefulness of the development concept been given any kind of careful examination. While it was possible to observe in r 969 that "job training cannot be compared with [community] economic development on an either/or basis," the $\mathrm{I} 966$ view was clearly in the manpower tradition, even though the questions being asked by the new HUD team and the congressional mandate suggested a much wider focus. Then, in late 1967 , HUD indicated that the comprehensive development program resulting from the initial-years' planning should provide (in the economics area) for projects and activities designed to achieve additional sustained employment opportunities and new careers in the public and private sectors. Without fully recognizing its potential, HUD also opened the door for community-based economic development by suggesting that manpower objectives might be met through the adoption of incentives designed to stimulate the expansion of commercial and industrial employment opportunities available to model neighborhood residents, add-

\footnotetext{
${ }^{10} I d$. $\$ 3303$ (a) (2).

${ }^{11}$ Green \& Faux, The Social Utility of Black Enterprise, in BLAcK Economic DeVELopment 2x, 23 (W. Haddad \&: G. Pugh eds. 1969).
} 
ing rather lamely that it may be necessary to encourage the development of "private enterprises" in or accessible to the model neighborhood.

It was not long thereafter that HUD acquired staff capability in the economic development area and separated that resource from its manpower function. In addition, the regional staff function was expanded to include economic development under the aegis of a manpower and economic development specialist. Thus, by the middle of 1968 HUD had developed a recognition of the development field and exhibited a limited ability to respond to locally-expressed desires and explore the concept of "Green Power." To provide the correct historical prospective, it must be noted that the first group of model cities (seventy-five, in all, chosen from I93 applicants) had just begun the planning phase of their programs, and thus, a correlation existed between the staffing available to service local needs and the recognition of those needs. The nature of HUD's response and the staff's role in enhancing the potential for economic development in the model cities during the coming decade have both greatly expanded as the communities in the program have matured.

\section{The Present HUD Stance on Economic Issues}

It is fair to say that HUD was dragged kicking and screaming (although not entirely unwillingly) into a new definition of economic issues and a more realistic view of the role that economic development might play in local Model Cities programs, and it now realizes that the cities recognize Model Cities funds as the most flexible and versatile source of government financing for economic development programs. The Department's current response is a positive one, designed to enhance community desires to attack economic issues at the development and control level. Staff competence has been upgraded and the number of people working directly or indirectly on economic development has been expanded. In addition, HUD has hired two consultants, one to provide general economic development technical assistance to a number of communities who are or appear as though they will be "getting it on," and the second to train local staft in the intricacies of community economic development and business packaging techniques. Thus, HUD's position may be described as generally supportive, with top staff not entirely convinced while mid-level staff, which is charged with the responsibility for economic development, is moving ahead in assisting communities to plan and implement strong programs of local design. ${ }^{12}$

\section{II}

\section{Economic Development in the Model Citres Program}

Having explored the Model Cities program, its genesis and HUD's response to economic issues as they affect economic development, we can now logically turn to

\footnotetext{
${ }^{12}$ Attached to this article as an appendix is the HUD Policy Statement on Economic Development, which states the administrative parameters within which economic development may be carried out in the Model Cities Program.
} 
the unique potential of economic development within local programs. The flexibility of the Model Cities program, its special relationship to federal and local resources, and its broad perspective create opportunities for economic development at the community level that do not exist to the same degree in most other programs and activities. That many of these avenues have not been extensively tapped to date is less important than the fact of their existence, for, in addition to the large financial resource that the Model Cities program makes available, these special opportunities are most exciting.

It has already been observed that local Model Cities programs are involved in a wide variety of traditional and not-so-traditional economic development activities, many of which are provided to the community through the CDC vehicle. The majority of these activities are similar in nature to programs being run all over the country and offer little that can be said to advance the state of the art. They are significant only because they rely on Model Cities funding for much of their financial resource and thus have been able to begin operations with at least one major hurdle aside.

The first part of the Model Cities planning year is geared to producing an indepth problem analysis of the neighborhood, including such information as income and employment statistics, business participation rate, economic base analysis, a limited view of the goods and services available in the neighborhood and who controls (profits from) them, ongoing social and physical development programs, and the extent to which the neighborhood is involved with or bypassed by the area economy and its infrastructure. Thus, because it is a component of a Model Cities program, the economic development function begins life with a built-in pathological analysis of the community it is to serve.

In addition to the analysis of the symptoms of economic deprivation, the model cities are expected to pinpoint specific causes which have created the observed conditions. Although these causal factors tend to be somewhat similar in every location, each community is plagued by any number of unique elements which separate it even from its closest neighbor. One need only look at such communities as East Los Angeles (heavily Chicano) and Watts (primarily black) to realize that the problems are sufficiently different from neighborhood to neighborhood as to demand different stategies and direction for each. The advantage possessed by those who would pursue economic development in the Model Cities program is that they are able to tailor their activities from the outset to best meet the conditions of their individual communities.

This is not to say that economic planning and analysis ends when the city moves into its first action year. The city is expected to continue its analytical activities and to extend the range and depth of its studies to provide the full scope of information necessary to make program evaluation and funding decisions a rational process. HUD expects this kind of activity and examines cities' problem analyses, goals, and 
objectives to see that project funding patterns are consistent with stated measures and direction.

The outcome expected after all this planning and analysis is a logically-constructed program with a well-reasoned purpose and sense of direction. To promote economic development, the typical model city will move to set up some kind of development corporation, and one of the niceties of the Model Cities program is the relative ease with which such corporations can be organized. Community political hassles which frequently accompany the establishment of an acceptable development effort are often avoided in the model neighborhoods because of the recognition that the Model Cities program has received and the ongoing organizational activities that have necessarily occurred due to the existence of the local program.

The development company's credibility, while dependent in the long run on its ability to make positive accomplishments, in the short run, at least, is subject to less suspicion than many similar efforts. In addition, the local Model Cities program has usually made contact with other organizations that have a specific stake in the neighborhood or may be doing or considering economic development. HUD strongly encourages this kind of interaction and monitors local programs to see that existing institutions and organizations are utilized to their fullest. Thus, in Seattle, Washington, the Model Cities program, rather than setting up its own captive economic development arm is funding the United Inner City Development Foundation to carry out its development objectives.

Control of development corporations and programs is one of the most difficult issues that must be faced in the establishment of a new economic development activity. Again, when done as part of a Model Cities program, the politics become more easy to handle, although no less critical. In the first place, the community has a major role in the selection of corporation members and the board of directors. HUD policy limits the neighborhood citizen participation body to direct appointment of one-third of the corporation's governing body and allows only one joint membership (for conflict of interest minimization). However, it is silent on the method to be utilized in designating the remaining two-thirds, and presumably the procedure to be followed will at least be satisfactory to the citizen board even though it plays no direct role in the final selection of the larger group. In any event, the policy does require that the corporate governing body be broadly representative of the community within the model neighborhood area while also providing that participation be sought from the wider city community in an attempt to provide specific expertise and access to the necessary management and financial resources controlled from without the model neighborhood. ${ }^{13}$

In contrast to nearly all other economic development funds (OEO I-D, ${ }^{14} \mathrm{EDA},{ }^{10}$

\footnotetext{
${ }^{13}$ See Policy Statement on Economic Development $\$ 7$ (197r), infra app. A, at 225.

${ }^{16}$ This is the so-called Office of Economic Opportunity Special Impact program developed pursuant to 42 U.S.C. $\$ 2763$ et seq. (Supp. V, r970).

${ }^{15}$ Economic Development Administration program regulations are set forth in $x_{3}$ C.F.R. $\$ 301 . x$ et seq. (1970).
} 
$\mathrm{SBA},{ }^{16} \mathrm{OMBE}^{17}$ foundation, churches, and so forth), which come directly into the community from the funding source, Model Cities funds may be viewed as local funds, because HUD disburses the funds to the city for distribution to the selected operating agencies. There is, therefore, a local contract with the development corporation, the contents of which are specified locally. As a result, the community, through the Model Cities process, can exert extensive control over the existence and actions of the development corporation. Many cities use the contract to provide direction and emphasis for their development programs, using controls on the type and amount of investment funds as well as criteria for their spending (job/capital/wage relationships), earmarking funds for specific projects (industrial parks, shopping centers, land acquisition), regulating staffing patterns and salaries (business packaging specialists, industrial recruitment specialists), and describing the expected focus of the program (small business/medium and large enterprise, service/manufacturing/retail, neighborhood emphasis/larger economy).

Community influence and control accrues in a number of additional ways. The Model Cities staff is the most common prime mover in pulling together all the organizational elements-choice of board members by those so enfranchised, articles of incorporation and by-laws, and contract with the corporation after its formation. Setting eligibility criteria for financial assistance is a local responsibility. Employment of model neighborhood residents in the jobs created by the development effort is a programmatic requirement and is included in the contract with the corporation. Regular reports, monthly and quarterly, are required from the corporations and these are reviewed by the community, which may choose at any time to seek suspension or termination of the contract with the corporation. In addition, the local programs carry on extensive evaluation programs, which provide data that is used in the yearly refunding process. Suffice it to say that in the Model Cities program, local control over economic development is substantial and may well exceed that afforded in programs where funding comes directly to the project from Washington, New York, or any other locus of development money.

For those communities designated as model cities, the program may be a source of funds second to none other available to them in carrying out their economic development programs. Annual expenditures of Model Cities moneys are approaching $\$ 600$ million. It is not unreasonable to expect that some eight to ten per cent of this amount, or $\$ 45$ million to $\$ 60$ million, will be allocated annually for a variety of economic development activities as the program matures. While $\$ 60$ million is not an impressive figure when measured against the needs of the model cities, it compares favorably with other sources of funding for community economic development and establishes the Model Cities program as a full member in the movement.

\footnotetext{
${ }^{10}$ Regulations governing Small Business Administration programs appear in 13 C.F.R. $\S$ ror.I et seq. (r970).

${ }^{27}$ Office of Minority Business Enterprise programs are administered under the Department of Commerce. See Exec. Order No. II,458, 34 Fed. Reg. 4937 (Ig69).
} 
What is perhaps more exciting is the flexibility of Model Cities funds in supporting nearly every stripe and hue of development. Aside from a number of restrictions imposed to avoid conflict-of-interest situations, HUD proscribes only one absolute constraint in the use of funds: Model Cities funds may not be extended to a forprofit enterprise to finance that enterprise on a grant basis. ${ }^{18}$ There is also a general proscription against the use of Model Cities funds on a direct-loan basis in the absence of participation by other financial institutions. ${ }^{19}$ It is the HUD position that even the softest of proposals, if it has a reasonable likelihood of financial success, can attract some "outside" financing if the Model Cities funds are used to advantage to bring in outside financing. In addition to possessing insufficient funds to assume the banking function, the Model Cities program (like other sociallyoriented programs) has a stated legislative goal and an obligation to change our major institutions, but not to supplant them.

\section{III}

\section{Program Financing}

The list of uses for economic development funds that the Model Cities program will support is much too lengthly to be examined here. Of interest is the leverage that a community can achieve in using its Model Cities financial resources to attract the large financial injections necessary to support a broad-based economic development effort. The widely-recognized need for venture capital is satisfied by very few sources of development funds. In the Model Cities program, this use of funds is encouraged. Loans may be made on a subordinated basis at favorable interest rates with advantageous repayment terms. Moreover, equity positions are frequently taken by the development corporations in return for their financial participation.

Another interesting use of Model Cities funds on a front-end basis is in providing the local matching share for capital facilities financed under the SBA section 502 program. ${ }^{20}$ Most packages brought to the SBA by section 502 Local Development Corporations associated with the Model Cities program have been considered eligible for ninety per cent loan financing, thereby requiring the community to supply only ten per cent of the total fixed facilities cost. Of course the community also benefits by its ability to retain ownership of the land and plant, which it leases to the assisted business concern at rates equal to or greater than the corporation's cash flow obligations on its section 502 borrowings.

Model Cities funds may also be risked for purposes other than the provision of front-end capital. Loan guarantees (usually on some kind of levered basis), interest subsidies, and other financial advantages such as deferred payments are frequently provided in conjunction with the deposit of Model Cities funds. A typical example involves an economic development corporation, funded by Model Cities, which was

\footnotetext{
${ }^{18}$ Policy Statement, supra note $13, \$ 5$.

${ }^{10} \mathrm{Id}$. $\$ 5 \mathrm{C}$.

${ }^{20}$ See I3 C.F.R. $\$ 108.502$ (1970).
} 
confronted with a number of small businesses needing loan financing. The banks were interested in considering each small package $(\$ 500$ to $\$ 5,000)$ on an individual basis provided that SBA guarantees were obtained. The development corporation, clearly seeing the inevitable frustration of carrying a large number of marginal packages through a complicated process, offered $\$$ roo,000 of its funds to guarantee a \$200,000 revolving loan pool provided by the bank to fund the corporation's small loan needs. It was further proposed that any loan recipient demonstrating a satisfactory earnings record over a two-year period be removed from the guaranteed pool and treated as an ordinary bank loan, since a seasoned loan no longer exhibits the element of risk that required the development corporation to act as guarantor at the time of financing. Such a procedure obviously would expand the funds available for other potential small business borrowers.

One of the constraints that most community development efforts must overcome is the need to provide a local matching share in order to receive federal funds and, in many cases, church or foundation funds. Any number of well-conceived programs have been delayed, abandoned, or have proceeded without adequate financing because of "buy-in" requirements imposed by funding sources. As troublesome as underfinancing has been for social service programs, it could well be fatal in economic development. Hopefully, this situation will be avoided in Model-Cities-related efforts. In the first instance, the Model Cities legislation specifically provides that funds "may be used and credited as part or all of the required non-Federal contribution to projects or activities, assisted under a Federal grant-in-aid program . . .."21 Second, the programmatic emphasis on the use of existing agencies would enable viable community agencies to enhance their relationships with funding sources since the localshare hassle will be eliminated by virtue of Model Cities support. Unfortunately, there is one major government program which does not accept Model Cities funds as the matching share. In the year or so that OMBE has been merchandising its Wunderkind, the Minority Enterprise Small Business Investment Company (MESBIC), a number of Model Cities agencies cleared the bureaucratic hurdles and set aside the initial capital necessary to receive a license to operate as a MESBIC. In each of these early cases the format differed, thus presenting OMBE and SBA with a choice of mechanisms by which a community with Model Cities backing could be allowed to function as an SBIC. Fresno, California, through the Fresno West Development Corporation, made application to be the sole source of financing for and sole owner-operator of a MESBIC which would become an integral part of its broad economic development program. The models proposed by Winston-Salem, North Carolina, and Atlanta, Georgia, were different in organizational structure but retained Model Cities funds as the source of their paid-in capital. Each plan was rejected as not meeting the legislative mandate that SBIC's be financed by substantially private capital. ${ }^{22}$ If the HUD operatives in Washington led by Assistant

\footnotetext{
${ }^{21} 42$ U.S.C. $\$ 3305$ (d) (Supp. V, 1970).

"See 42 U.S.C. $\$ 682(1964)$.
} 
Secretary Floyd H. Hyde and his economic development advisor, Norman DeWeaver, are not successful in their efforts to dissuade SBA from its restrictive interpretation of the SBIC legislation, the local Model Cities programs will have to develop less direct, more complicated strategies to obtain the obvious benefits derived from community control of the MESBIC mechanism.

One gambit that has been tentatively approved by SBA suggests the use of Model Cities funds to pay the operating costs of a MESBIC, the capitalization of which is provided by acceptable sources. This, of course, means that the Model Cities development agency must become involved in a search for funds from foundation, church, or private financial sources or by sale of stock. Not answered, at this time, are the questions of ownership and control of the board of directors. One can only guess that ownership would not be allowed to pass to the community, and, on the other hand, that SBA would not prevent community representation on the board of directors and community participation in selecting the staff and in determining the operating policies of the MESBIC.

The opportunity to undertake large-scale economic development, through enterprises capitalized in the hundreds of thousands of dollars, requires substantial financial resources. Many development efforts simply cannot function in these terms, because their funds are too limited and their leverage with the wider financial community almost nonexistent. Here again, programs linked with Model Cities have a built-in advantage. Many are expressly funded to attempt development of large-scale enterprises. Those that are not so funded are able to turn to the local model cities progam if they have reasonable prospects of putting together a substantial package.

In addition, Model-Cities-related efforts have both the financial and technical resources necessary to react quickly and responsibly to targets of opportunity that present themselves at random intervals. A typical situation, for which no rational planning is possible, would be a spin-off opportunity presented by a large corporation. Howsoever motivated, whether out of guilt, public self-interest, profit, or true belief, the corporate liberal demands quick action and, frequently, substantial monetary commitment in exchange for his setting up a captive enterprise in the community. Very few Model Cities need allow opportunities of this nature to go untapped. If the conjecture is true that uses of the spin-off technique will expand rapidly from the thirty or forty that have been attempted in the last few years, and if the best strategy for success involves an active partnership with the community in planning and creating the spin-off corporation, then Model Cities development agencies ought to be in a unique position to assist their communities in initiating as well as exploiting spin-off opportunities.

Much of the benefit suggested above can accrue to any community development effort that possesses adequate, flexible financial resources. Notwithstanding the fact that most of the new enterprises are required to run the gauntlet of private financial interests in order to reach fruition, economic development in the Model Cities pro- 
gram begins with the not inconsequential advantage of having adequate funding to make the best of any opportunities that it stumbles upon or generates.

\section{IV}

\section{Opportunities Available to the Model Cittes}

Even with the critical problem of financing reduced to more manageable proportions, the actual establishment of viable businesses that will achieve the multifaceted goals of creating meaningful, well-paying jobs for large numbers of people, increasing the numbers and skill levels of middle management in the community, providing the community with greater control over the economic fortunes that govern people's lives, and creating new institutions that provide the community with substantial capital and capital-generating instrumentalities together with the skills to use that capital remains a problem in the Model Cities program as in any other community development activity. The suggestion that development efforts associated with Model Cities have an advantage in achieving these goals is not made lightly. The creation of viable enterprises is recognized by all as being a tough, tricky business in which the risk of failure is high. Because of their special relationship to the total community improvement effort of the Model Cities program, and because the Model Cities program is one of the federal government's major urban programs-and certainly its most comprehensive urban program-a number of unique opportunities exist to interface economic development programs with a wide variety of federally- and locally-initiated programs and activities of a more narrow scope. A number of these advantages which accrue in the Model Cities program are examined below, not so much in a how-to-do-it exposé, but rather with an eye toward increasing public recognition of them. Each might legitimately be the topic of a lengthy treatise, and the space devoted to them below is hardly indicative of their importance in this area.

\section{A. Core Strategy Concept}

The first of these, the core strategy concept, is almost totally unique to Model Cities. As noted above, each city participating in the program is expected to identify its specific problems, set goals and objectives that have local relevance, and develop a strategy to achieve those goals and objectives. A city whose community leaders and administration fully recognize the devastating effect of prolonged economic deprivation might well elect to concentrate its efforts on economic development. The legislative purposes of the program-“"to rebuild or revitalize slum and blighted areas; to expand housing, job, and income opportunities; to reduce dependence on welfare payments; to improve educational facilities and programs; to combat disease and ill health; to reduce the incidence of crime and delinquency; to enhance recreational and cultural opportunities; to establish better access between homes and jobs ...."23-all can be defined in economic terms and, therefore, could lead many

${ }^{28} 42$ U.S.C. $\$ 330$ I (Supp. V, I970). 
communities to attack these conditions through a program emphasizing economic development as the core strategy. This is not to suggest the absurd result that schools, hospitals, parks, and other social services delivery systems be established on a profit-making basis; rather, the enhancement of these systems will provide opportunities for development of real capital, through construction and related operational activities, as well as for the development of human capital to enable the community to participate fully in the economic gains that are being made.

An economic-development core strategy dictates that in addition to funding new business development, other Model Cities projects provide supporting services which enhance the community's ability to make economic progress. Thus, public improvement projects can be designed to increase the desirability of the neighborhood as an industrial location. Local contractors would receive technical assistance, enabling them to take on larger, more complex projects, as well as financial backing, which would provide operating capital for bonding and interim cash flow needs. Affirmative action programs, stated quantitatively and incorporated into the project bid specifications, would insure that area residents received the construction jobs generated. Manpower training projects would be keyed to the program's skill requirements, the majority of which ought to be identifiable during the planning period and would thus prevent skills training for nonexistent jobs. The primary thrust of educational programs would be the development of business management, professional, and technical skills needed to make the neighborhood self-sufficient in terms of its ability to run its own enterprises without resorting to imported labor. Housing development, a high priority desire of many Model Cities programs, would be related to the core concept through assistance to local contractors' affirmative action programs, the funding of nonprofit housing sponsors, and attempts to generate real estate development enterprises. The funding of housing activities would be timed to meet the demand created by the cash flows brought into the neighborhood through the economic development program.

Central to the economic development core strategy concept, of course, are the financial relationships among its various elements. Each must be funded in such a way as to produce a result which supports the other elements in the program. Funding for economic development would necessarily anticipate the cash and management assistance needs of the businesses generated by economic leverage derived from the social and physical sections of the program as well as from larger-scale, externallyfocused business development.

Although the economic development core strategy concept is utopian rather than real at this point, a number of cities have achieved a moderate level of programmatic integration between economic development and other aspects of their Model Cities action programs. Inasmuch as the majority of model cities will not opt for the core strategy but will attempt some kind of economic development, it becomes important that programmatic linkages be achieved wherever possible. 


\section{B. Manpower Training}

Clearly, the most obvious linkage is the relationship with manpower agencies. Any aggressive economic development program should be creating businesses and jobs. ${ }^{24}$ Although the percentage will vary from program to program, a large number of these new jobs will require skill levels not possessed by most unemployed and underutilized community residents. By using its manpower funds to provide the training necessary to place residents in the new jobs, the Model Cities agency is guaranteed a maximum return on its expenditure, since training is provided for jobs controlled by the Model Cities program; and, at the same time, the model neighborhood's desirability as an industrial location is enhanced, since any new business is guaranteed a trained labor force at no expense.

In spite of the plethora of manpower training funds being spread over the land by an overwhelming variety of agencies, manpower resources paid for or controlled by the Model Cities program may be better suited for the community and, at the same time, more supportive of economic development than one normally expects. The key is flexibility to match people to training resources and guaranteed jobs. Model Cities development programs have, in some instances, been geared to providing job opportunities for the hard-core unemployed. The need for extraordinary training, counselling, and support is obvious. As a result, many existing manpower training programs cannot meet the high costs and will not tolerate the high frustrations of working with the hard-core. Naturally, Model Cities training resources have been required in these instances. Although the program is too new to provide definitive data, early results have suggested that placing the hard-core unemployed in local businesses, possessing more community orientation than is typical of private enterprise, can help overcome work hang-ups ${ }^{25}$ experienced by the poor.

The use of Model Cities funds to train higher-income community people for the more highly skilled jobs-foreman, steward, and so forth-again insures any business locating in the model neighborhood of a supervisory force which is not only already trained but which is also likely to be more acceptable to the labor force than imported supervisors. The same is true for any of the various levels of management, all of which may be filled with people trained with local Model Cities funds.

\section{Improving Housing}

In addition to manpower, the other Model Cities element most often related to local economic development is housing. Almost every model city perceives inadequate housing as a major deficiency. It is not a recent phenomenon that the supply of housing in minority communities is inadequate both in terms of amount and quality. The housing squeeze in most major areas of urban concentration has only compounded the difficulties. As the various model cities have moved to alleviate

\footnotetext{
${ }^{24}$ And, according to the Model Cities gestalt, these jobs must be filled primarily with residents of the model neighborhoods.

${ }^{25}$ Which are frequently referred to as reflecting lack of knowledge of the "world of work."
} 
the housing burden, many have appreciated the linkage that housing development can have to economic development.

A nonprofit housing sponsor (a frequent Model Cities mechanism) is, in many ways, not unlike a new business. The management problems have many interesting parallels ${ }^{26}$ which are no less difficult for the new housing manager than for the new business manager. If the failure rate is lower, it is only because it is more difficult to kill a house in a market with no vacancies-such as the ghetto market for standard, reasonably-priced housing-than it is to kill a business. To guarantee that the ModelCities-financed nonprofit housing sponsors provide adequate management for units which are very precious to the community, many cities have made the housing management assistance function part of the economic development technical assistance function, thereby purchasing more specialized services in both areas for the same cost-and without setting up two separate staffs.

As mentioned above, there is a need for housing development to meet the demand created by a new group of well-paid, private-sector workers in the community. Even though the Model Cities program is still too young to have reached that glorious day, the normal program does generate jobs in the public sector, the income from which is already creating a modest housing demand. Presently, the most advanced cities are moving into position to establish their own profitmaking real estate development corporations to build moderate amounts of non-assisted housing in the model neighborhoods. From that experience, those firms should be able to move into the larger housing market at a time when the demand for housing is about to explode.

There is, of course, one additional, obvious advantage that Model Cities programs have in setting out to develop assisted or non-assisted housing, whether or not the linkage to economic development is made. For whatever it may be worth, local Model Cities programs, by virtue of their HUD connections, have some leverage in getting FHA commitments to provide financial assistance and guarantees for housing that is being built in conjunction with the program.

A frequently-discussed but as yet untried gambit related to solving the model neighborhood's housing problems is the formation of a modular housing corporation. The typical model foresees the economic development corporation providing the venture capital, the banks and SBA putting up the loan funds, neighborhood residents being trained as the company work force, and the pent-up demand for low- and moderate-cost housing in the model neighborhood providing a guaranteed market. The problem, of course, with this synergistic system is that the market cannot be guaranteed unless the Model Cities program finances all the housing and the community is willing to accept a standardized product-not just for one or two clusters, but for all new housing. In any event, the market that could be guaranteed would probably not be of sufficient size to meet the minimum produc-

\footnotetext{
${ }^{26}$ Accounting, purchasing, record-keeping, advertising, and site selection are only a few of the common problems.
} 
tion required for a plant to be financially feasible. The economic constraint that most cities thinking along these lines must face is either the necessity to compete in the open market economy ${ }^{27}$ or to expand the size of their guaranteed markets, a question of economics which is explored below.

\section{Minority Contractors and Urban Renewal}

Related to new housing development is the question of how the Model Cities program goes about enhancing the opportunities for minority contractors. For the most part the techniques being used are not unique to the program and are not very successful. Generally, the training and assistance programs are well financed, but the bonding problem has not been successfully approached. Revolving pools for working capital and bonding have been established by many cities, but the funding has not been very significant when compared to the need. While it will not solve the financial problem, there is a means within the Model Cities program for cities to channel more construction activity to contractors from the model neighborhood. The mechanism utilizes the employment-of-model-neighborhood-residents requirement to prevalidate acceptable bidders on the basis of their demonstrated ability to hire residents for construction projects. Under this system the local minority contractor, whose regular work force already lives in the community, gets the advantage.

The ability to help minority contractors and, at the same time, to realize significant economic gains for the community also occurs when HUD's Urban Renewal program is used in conjunction with economic development efforts of Model Cities. The contractors can always participate in the demolition process, which is under public control. However, they rarely get assigned any of the rebuilding activity; the bulk of that is done by private, multimillion dollar land developers who choose their own contractors, and not necessarily by open, competitive bid. When the community controls the process, minority firms are more likely to participate in the reconstruction work, and that requires very effective community organization in the most political way or community control of the land in the capacity of developer. In point of fact, many Model Cities are proceeding in this manner. Communities are putting themselves squarely in the running to become developers of urban renewal projects, backing up their organizational strength with Model Cities money. As in the housing field, the HUD lineage of both Model Cities and urban renewal is a distinct advantage.

Control of land is an important asset for any development effort. Up to this point, the communities seeking to link urban renewal with economic development have focused on projects started long before Model Cities and economic development were heard of. As the result, the projects are not entirely suited to Model Cities needs. Moreover, the community economic development effort has had to catch up rapidly to avoid missing yet another payday. These handicaps can be overcome, however, and no community with the financial and political strength of the Model

\footnotetext{
${ }^{27}$ This would require a very different image for the product to be produced.
} 
Cities program behind it ought to remain idle because the game started before it was ready.

The far better, if longer term, relationship with urban renewal is the one initiated by the local Model Cities agency as part of its economic development program. In this instance, the community is clearly involved from the very beginning. It participates in all critical decisions, including site selection, timing of the project to proceed in line with the community's capability to respond, and planning the eventual re-use of the project. In addition, and possibly most important, the entire cost of buying the land and preparing it for resale can be funded with readilyavailable HUD funds. Renewal funds to be used in conjunction with the Model Cities program have been more readily available than normal renewal moneys, since the local matching one-third share may be paid from Model Cities grants. By using the renewal process to its best advantage, local model cities programs can easily assemble parcels of land whose size and location are best suited to the needs of their economic development programs. As with any Model Cities activity, land assembled in this manner need not necessarily be included in the model neighborhood area; however, the benefit to be derived from the re-use of the land must accrue to residents.

Having followed the procedure outlined above for new projects or the more difficult route for ongoing projects, the development corporation should be in a position to receive the first-development option on the land of a no-fee basis. The trick, then, is to take advantage of long-term leases to finance the land and plant, turnkey operations for construction contractors, and employment contracts with the eventual users of the land to ensure employment of local residents.

\section{E. Relations with Other Programs}

Local Model Cities programs have a special relationship to the institutions that control city planning activities, zoning, taxation, public improvement programs, and other local services that affect a community's ability to make economic gains. An enlightened city, making strategic use of its powers and resources, can provide very valuable assistance to a community economic development effort. In many instances, nothing more is involved than the everyday courtesy of one city agency clearing the way for another's program. On the other hand, the early provision of such public services as roads, lighting, water, sewers, and trees in an industrial setting can be the key factor in making a community's development effort successful. Model Cities programs needing city support in order to accomplish their economic objectives are given a big assist by HUD, which pays regular and close attention to the level of city commitment and the manner in which regular city functions help or hinder the city's program.

Just as development efforts related to Model Cities enjoy a favored position within the normal functions of the city government, so also do they frequently enjoy a position of greater credibility with the private sector than do most other community- 
based programs. The reasons for this are many, including the program's presupposed good relations with City Hall, the additional relationship with the private financial institutions in the area of housing, and the broad city involvement that usually accompanies Model Cities. The frequent upshot of this advantage is a heightened ability to bring about institutional change, making the private sector more responsive to the community's economic and financial needs. Whereas many programs (such as OMBE) to date have set out to increase the number of interactions between community and downtown, Model Cities also seeks to change the nature of that interaction. Proposed programs in New York City, Tucson, Fresno, and Baltimore involving Model Cities and bank-sponsored credit arrangements attest to the potential in this area.

We have already explored the unique ability of Model Cities funds to be used as the local matching share for other federal grant programs. It is worth noting that the model neighborhood areas comprise geographical and pathological units which make then ideal candidates for the benefits available under EDA's Special Impact designation and OEO's Speical Impact (I-D) program. Several model neighborhoods are expected to be among the few urban poverty pockets that EDA will designate for special assistance. (HUD, of course, has suggested to no avail that EDA designate all I50 model neighborhood areas on the basis that their inclusion in the Model Cities program is prima facie evidence of satisfying EDA guidelines.) Under OEO's I-D program, the United Inner City Development Foundation in Seattle, which has been receiving Model City funds, has been chosen as the recipient of a six-month grant to plan specific enterprises and activities which OEO will fund. By joining a CDC operating with Model Cities funds, the OEO grant realizes significant savings in start-up time, staff orientation, and community acceptance.

As a program, Model Cities have suffered the advantages and disadvantages of being restricted to serving the populace of a given geographic area. One of the positive aspects of that constraint is the understanding of a particular neighborhood that arises over a period of time. In the economic area, this means that markets are measured, business expansion potential is well-evaluated, strengths get exploited, and weaknesses are corrected. In short, economic programs are beginning to achieve their first blushes of maturity. The Model Cities agencies located in close proximity will then be in position to work together in capturing the potential of their several marketplaces, thereby expanding the size and types of business which might logically be started to serve the community.

One very legitimate example of this could well be a modular housing factory sponsored by a number of model neighborhoods. If the potential market for the factory's product can be increased, its prospects for financial success would seem to be far greater than those of the factory built by a single Model Cities program to serve its neighborhood only. The many Model Cities programs in the San Francisco area have indicated a willingness to explore a joint approach to their financing 
problems at a reasonable point in the near future. Jointly-funded venture capital, venture management, and technical assistance operations are also logical extensions of the economic development programs beginning to function in the many model neighborhoods. In time, of course, the natural alliance that will grow among the Model-Cities-sponsored development efforts in 150 cities will be expanded to include CDC's and all other types of community-sponsored groups.

\section{ConcLuston}

The upshot of these many unique economic and political advantages accruing to Model-Cities-related development programs should be a higher degree of success than the average community development program experiences. In some cities, success will be spectacular; in others, failure will be equally spectacular. Although they will be the exception, a few moderately-sized cities with aggressive programs, can be expected to ameliorate much of their unemployment problem and to establish the kind of viable community-based enterprises and institutions necessary to continue the development pattern. For most, however, success will be achieved in terms relative only to lesser efforts in the past. Success, absolute success, will be too difficult to achieve within the time frame allotted, with the financial resources provided, and with the backdrop of a nation not very willing to accept its responsibility to its poor.

\section{APPENDIX A}

\section{Policy Statement on Economic Development (CDA Letter ro-C)}

\section{General Considerations}

In undertaking economic development projects, each City Demonstration Agency must carefully weigh the full range of approaches to development problems. This examination should enable the CDA to choose the approach or combination of approaches most appropriate to its problem analysis. The various development approaches to be considered may include, but are not limited to:

a. Economic planning in order to utilize the area's physical and human resource base more efficiently.

b. Furnishing technical assistance to businesses and development organizations.

c. Financing development activity and individual business ventures.

d. Creating and improving the public facilities and services necessary for economic growth, such as development of industrial sites, transportation systems, water, sewerage and other utilities intended to benefit industrial and commercial users.

e. Impacting municipal policies and practices on land use, taxes and other matters which affect the city's ability to attract investment, particularly in the Model Neighborhood. 


\section{Use of Existing Organizations}

Existing organizations, institutions, programs and services shall be used to the optimum extent possible in implementing economic development projects. CDAs are required to demonstrate the ways in which such existing resources will be involved in performing economic development tasks at the time action plans to be supported from supplemented funds are submitted to HUD-Model Cities for approval. Such submission material will be supplied in accordance with the Issuances or Instructions that are contained in Category 3r40 entitled Submission Requirements of the Model Cities Operating Manual.

\section{Relationship to Other Components}

CDAs shall extend all appropriate services from other components to support economic development projects. Specifically, manpower training and development services shall be provided to help qualify Model Neighborhood residents for jobs generated by economic development activity and to help residents retain and become upgraded in such employment. Supporting services, such as child care and transportation, shall be arranged where appropriate.

\section{Technical Assistance Functions}

CDA action plans should clearly identify the technical assistance elements of economic development projects and distinguish them from the investment elements listed in Section 5 below. Such a distinction is intended to facilitate application of this policy with respect to those costs chargeable against supplemental funds on a grant, loan or equity investment basis. Technical assistance elements which can be provided from Model Cities supplemental funds on a grant basis may include, but are not limited to, the following:

a. Performing feasibility studies, marketing surveys and labor market analyses concerning proposed expansions of existing businesses, the initiation of new business ventures and creation of new opportunities for investment.

b. Providing assistance in the packaging of loan funds or other financial assistance for individual business enterprises.

c. Furnishing management assistance to business enterprises, including but not limited to counseling in production, finance, marketing, procurement, personnel management and similar aspects of business operations.

d. Identifying prospective owners, investors and managers of business enterprises and training both potential and actual owners and managers in the techniques of business management.

e. Performing common services which increase the capacity of a businessmen's association to provide management training and assist in solving mutual problems for its members on a continuing basis.

f. Performing industrial solicitation and promotion functions. 


\section{Investment Functions}

The types of investment in individual business enterprises permitted with Model Cities supplemental funds shall be limited by the following rules:

a. Supplemental funds should not be used on a grant basis to finance a business.

b. Every effort shall be made to obtain the participation of private lenders in financing businesses. Where applicable the programs of the Small Business Administration, Economic Development Administration, State lending agencies and other public programs should also be used. Model Cities supplemental funds may be used in conjunction with such private and public lending activities in a variety of ways: to guarantee loans, to provide reimbursement to lenders of all or a portion of the interest charged on loans, to permit the deferred payment of principal or interest on loans, to facilitate special deposit arrangements encouraging the participation of private banks in business development programs or to provide a portion of the total loan financing required by a business venture.

c. Model Cities supplemental funds should not normally be used to provide loans to business enterprises in the absence of participation by other lenders or guarantors.

d. Supplement funds may be used to acquire equity in the ownership of an individual business only when such investments are not prohibited by State or local law and only when the development corporation or agency taking such an equity position is a nonprofit organization, or, if a for-profit organization, it is broadly-based and controlled by residents of the Model Neighborhood.

\section{Investment Guidelines}

In administering investment programs of the types permitted above, operating agencies shall observe the following procedures:

a. Prior to using supplemental funds for investment purposes, the agency operating the component project must ascertain the potential viability of the proposed business venture. If the owners or managers of the proposed business do not have experience in the successful operation of similar ventures, management assistance must be provided as appropriate to insure the success of the venture.

b. Any financial assistance furnished to a business shall be conditioned upon a requirement that all employment generated will be available on a preferential basis to Model Neighborhood residents in accordance with HUDModel Cities policy on resident employment. Such financial assistance will be further conditioned upon a requirement that the business will conform to HUD policy on equal opportunity.

c. Agencies administering investment programs shall establish criteria under 
which proposed ventures shall be eligible for financial assistance.

d. In addition, agencies administering investment programs shall establish objective criteria under which preference will be given among proposed ventures meeting the eligibility requirements set in accordance with $c$. above. Such preference criteria may include: ventures which support other aspects of the Model Cities program, investments in labor-intensive businesses, and business ventures which provide subcontracting opportunities to Model Neighborhood enterprises.

e. The agencies administering investment programs financed with supplemental funds must maintain for public inspection copies of the eligibility and preference criteria required by $c$. and $d$. above, together with a list of the businesses assisted by such investments. This list must include the names and addresses of the businesses together with the names of the proprietors, partners or those shareholders who hold more than $20 \%$ of the outstanding stock in the corporation. Records should be kept of all applications for assistance received, including those which are not approved. Such records are necessary for internal evaluation and need not be available for general public inspection.

\section{Structure of Development Corporations}

Prior to creating any new economic development corporations, the CDA must demonstrate that there are no experienced, existing institutions performing the same or similar functions or else justify any decision not to utilize the services of such institutions. Any newly created development corporation or other private organization which receives investment capital from Model Cities supplemental funds for reinvestment in individual business enterprises shall be organized in such a manner as to comply with applicable Federal, State and local statutes. In addition, new development corporations shall meet each of the following requirements:

a. The governing board must be broadly representative of the community within the Model Cities target area. In general, participation should also be sought from the broader city community. Participation by private businesses, individuals and agencies with particular expertise in economic development shall be provided, either on the governing board or in advisory capacity.

b. No more than one-third of the members of the governing board may be selected, directly or indirectly, by the citizens participation body which serves the city demonstration program.

c. In designing the structure of the development corporation and composition of its governing board, CDA or other local officials should consider the the requirements of the various public programs which can provide capital 
to the development corporation. For example, if the development corporation expects to participate in the development and financing of land, buildings and equipment for small businesses, it should be organized in such a way as to meet the requirements imposed by the Small Business Administration on local development corporations under its Section 502 program.

d. Prior to considering any applications for financing which involve Model Cities supplemental funds, the development corporation shall establish rules prohibiting conflict of interest by development corporation officials responsible for determining the investments the corporation will make. 